\title{
Survey of Estrogenic Activity of Organic Extracts from Water Body from Jilin City Reach of the Second Songhua River
}

\author{
Hongyan Wang \\ School of Public Health \\ Beihua University \\ Jilin ,China \\ e-mail: wdj5210@163.com \\ Yanli Xi \\ School of Public Health \\ Jilin Medical College \\ Jilin ,China \\ e-mail: xiyanli@126.com
}

\author{
Jing Zhang \\ School of Public Health \\ Beihua University \\ Jilin ,China \\ e-mail: zhangjing@126.com
}

\author{
Shuguang Jin* \\ School of Public Health \\ Beihua University \\ Jilin ,China \\ e-mail:bhjinshuguang12345@126.com \\ *Corresponding author
}

\begin{abstract}
Objective:To survey estrogenic activity of Environmental estrogens (EEs) pollution in Songhua River water of the second Songhua River.Methods: human breast cancer MCF-7 cell proliferation experiment were used to detect estrogenic activity of organic extracts of organic extracts from water body. Results : MCF- 7 cell proliferation rate increased at first and later decreased with the organic extracts concentration. Bcl-2 mRNA expression of MCF-7 cell increased and Bax mRNA expression decreased with the concentration of organic matter. Cell proliferation was the fastest in organic extracts group equivalent to the raw water $1000 \mathrm{mLConclusion}$ :The organic extract could promote cell proliferation through the regulation of $\mathrm{Bcl}-2$ and $\mathrm{Bax}$ expression. The harm risks on the human body of the organic matter in water still need further research on environmental toxicology and epidemiology.
\end{abstract}

Keywords-water pollution;organic extracts; estrogenic activity; MCF- 7;Bcl-2;Bax

\section{INTRODUCTION}

Environmental estrogens (EEs) endocrine disruptors are a kind of estrogenic compounds, which can imitate or interfere with the physiological and biochemical effect of natural hormone including synthesis, release, transport, metabolism process, can activate or inhibit the regulated function of endocrine system. Finally they may produce a variety of toxic effects such as organs anomalies, male feminised and so on ${ }^{[1,2]}$ In recent years, Survey shows that incidence rates of hormone dependent tumor increased, especially the incidence of breast cancer increased year by year. Researchers have reported that the organic matter from water body in the Yangtze River and Jialing River and Hanjiang River and other river could productive estrogenic effect. Although the concentration of EEs in water is very low, even ng or microgram level, its impact on human, biology and descendants of the endocrine system is potential and significant, even in the "acceptable low concentration ", these compounds can cause a significant effect on the reproductive system ${ }^{[3]}$.

Songhua River is the main water source of people's life and economic development in Heilongjiang and Jilin Province. But Songhua River has suffered from the pollution and organic matter is one of the important pollutants. Therefore, the estrogen responsive human breast cancer MCF-7 cell proliferation experiment were used in this study to detect estrogenic activity of organic extracts of organic extracts from water body from Jilin City reach of the second Songhua River, to understand the secretion interferent pollution situation and distribution characteristics of river water estrogenic activity of organic extracts

\section{MATERIALS AND METHODS}

\section{A. Cells, reagent and instrument.}

Human breast cancer MCF-7 cells (Toxicology Research Center of Beihua University).DMEM cell culture fluid (Gibco); trypsin (Sigma), calf serum (Sijiqing Biological Engineering Research Institute in Hangzhou ), activated carbon / dextran treated fetal serum ( Hyclone company), dimethyl sulfoxide DMSO (Beijing Dingguo biotechnology limited liability company), MTT (Sigma), 17ß-estradiol, dextran 40000 (Beijing chemical reagent company).Bcl-2, Bax primers provided by Shanghai Yingjun Biotechnology Co., Ltd. TRIzol (Invitrogen company of the United States),reverse transcription (RT) -PCR kit (Fermentas company of the United States ) . 


\section{B. water sample collection}

According to monitoring scheme about water pollution the sampling point were set in upstream, midstream and downstream of Jilin City reach of Songhua River in August in 2012, each sample water depth was below the water surface at $0.5 \mathrm{~m}$.

\section{C. water sample treatment}

Organic pollutants in water samples was extracted by XAD-2 macroporous resin cleaned with organic solvent at column flow rate of $30 \mathrm{ml} / \mathrm{min}$, adsorption of organic compounds on the resin was eluted with $50 \mathrm{ml} 30 \%$ methanol and acetone elutant. Eluent was volatiled in $45^{\circ} \mathrm{C}$ water bath, then the residual was dissolved by DMSO and set the volume at $5 \mathrm{ml}$ (the water organic extract contained in $1 \mathrm{ml}$ DMSO solution was equivalent to those in $40 \mathrm{~L}$ raw water samples ); The DMSO solution was filtrated and stored at $4^{\circ} \mathrm{Crefrigerator}$ for further studies.

\section{MCF-7 cell culture and groups}

MCF-7 cells were cultured in RPMI1640 culture medium containning $100 \mathrm{U} / \mathrm{mL}$ penicillin ,100 $\mathrm{mg} / \mathrm{L}$ streptomycin and $10 \%$ fetal serum under $37^{\circ} \mathrm{C}, 5 \% \mathrm{CO}_{2}$ volume fraction and the relative saturation wetness. The test were set the negative control group (DMSO), experimental group (organic extract amount was equivalent to content of $100,500,1000$ and $2000 \mathrm{~mL} / \mathrm{ml}$ water of the original water) and the positive control group $\left(10^{-8} \mathrm{~mol} / \mathrm{L} 17 \beta\right.$ - estradiol).

\section{E. Calf serum removed hormone preparation}

$0.25 \mathrm{mg} / \mathrm{ml}$ dextran was added up in neonatal calf serum, $2.5 \mathrm{mg} / \mathrm{ml}$ active carbon was added after it is completely dissolved.Then they were centrifugated (3000r/min) for 10 minutes after bathed $45 \mathrm{~min}$ at $55^{\circ} \mathrm{C}$ water. The supernatant was kept to be treated 2 times in the above manner to remove estrogen in calf serum. The treated serum was filtrated with the metal filter $(0.45 \mathrm{~m}$ and $0.22 \mathrm{~m}$ two layer filter) and stored at $-20^{\circ} \mathrm{C}$ for further studies

\section{F. MTT experiment}

MCF-7 cells in logarithmic growth phase was digested with trypsin and rinsed with PBS, then vaccinated in 96 pore plate at $3 \times 10^{4}$ /every pore. The culture medium was abandoned after cells fully adherent $24 \mathrm{~h}$. Each hole is added $200 \mu \mathrm{L}$ culture fluid containing different concentrations of organic extracts, the control group is added with fresh culture nutrient. Each group has 4 parallel samples. All cells were cultured $48 \mathrm{~h}$ under $37^{\circ} \mathrm{C}$, $5 \% \mathrm{CO}_{2}$ incubator, then $20 \mathrm{~L}$ MTT solution $(5 \mathrm{mg} / \mathrm{mL})$ was added in each hole and cultured for $4 \mathrm{~h}$. Discard supernatant, add $150 \mathrm{~L}$ DMSO per hole, oscillate10 min under $37^{\circ} \mathrm{C}$, determinate optical density values D (490), and calculate the growth rate, which expressed proliferation of MCF-7 breast cancer cells.

$\mathrm{PR}=\mathrm{D}$ in the experimental group (490) / control group $(490) \times 100 \%$

\section{G. Bcl-2 and Bax mRNA expression detected by RT-PCR}

MCF-7 cell in logarithmic growth phase were inoculated into 6 well plate after digested by trypsin. After the cells adhered, each hole is added culture fluid containing different concentrations of organic extracts and kept $48 \mathrm{~h}$, then total RNA was extracted according to TRIZOL kit, RNA concentration and purity was detected through spectrophotometer, cDNA synthetized according to the reverse transcription kit and amplified in PCR instrument. Bcl-2 primer: upstream: 5' TGTGGCCTTCTTTGAGTTCG-3, downstream:5 'TCACTTGTGGCTCAGATAGG-3', the amplified fragment size was 215bp; Bax primer :upstream: 5 'GCGTCCACCCAAGAAGCTGAG-3', downstream :5'ACCACCCTGGTCTTGGATCC-3',the amplified fragment size was $300 \mathrm{bp}, \beta$-actin gene as a reference, upstream: 5 '-TACATGGCTGGGGTGTTGAA-3'; downstream: 5 '-AAGAGAGGCATCCTCACCCT-3', the amplified fragment size was $300 \mathrm{bp}$. The amplified product was confirmed by $1 \%$ agarose gel electrophoresis, strip was analysis through image scanner photographs, the gray ratio of purpose belt to reference band represented the relative expression of mRNA. The experiment was repeated 5 times, results expressed with mean value.

\section{H. Statistical methods}

Statistical analysis was performed using SPSS 13 statistical software, Groups were compared using univariate analysis of variance, and were considered to be statistically significant at $\mathrm{p}<0.05$.

\section{RESULTS}

\section{A. Effect on proliferation of MCF-7of organic extracts}

From figure 1, in the same sampling section, the cell proliferation rate of $\mathrm{MCF}-7$ treated with different concentrations of organic extracts increased at first and later decreased, showing the dose-response relationship for certain. The cell proliferation rate is very high in organic extracts group equivalent to the raw water 1000 $\mathrm{mL}$, which indicated that cell proliferation was the fastest, estrogen effects was the strongest. But the cell proliferation rate decreased in organic extracts group which is equivalent to the original $2000 \mathrm{~mL}$, and showed the toxic effect. The estrogenic activity of organic extracts from the midstream and downstream water samples were higher significantly than that of solvent control group $(\mathrm{P}<0.05)$; while from the upstream water, the estrogenic activity of the organic extracts of cultured in 1000 and $2000 \mathrm{ml}$ was significantly higher than that in the solvent control group $(\mathrm{P}<0.05)$, and there was not statistically significant $(\mathrm{P}>0.05)$ among cells cultured in $100,500 \mathrm{ml}$ with control group.

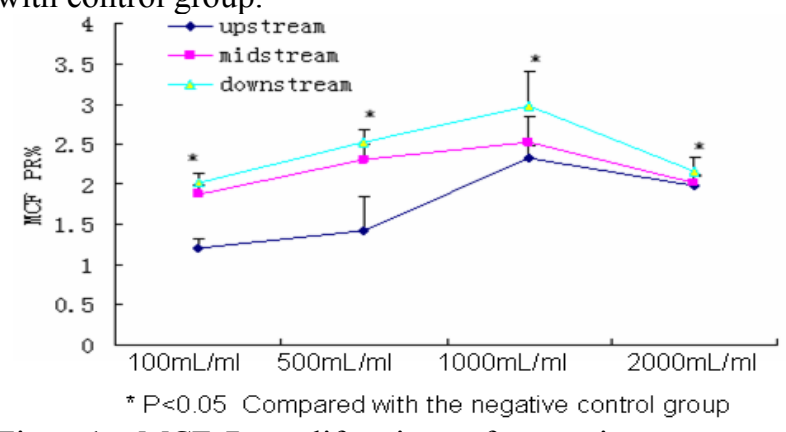

Figure1. MCF-7 proliferation of organic extracts of Songhua River 


\section{B. Effect on Bcl-2 and Bax mRNA expression of MCF- 7of organic extracts(Figure 2,3)}

In the same sampling section, there is a certain dose response relationship between $\mathrm{Bcl}-2$ or bax mRNA expression with extract concentration. Bcl-2 mRNA expression of MCF-7 cell was increased at first and later decreased. On the contrary, Bax mRNA expression of MCF-7 cell was decreased at first and later increased. The expression of Bcl-2 mRNA was the highest and Bax mRNA expression was lowest in organic extracts group equivalent to the raw water $1000 \mathrm{~mL}$, which suggested that organic extracts could inhibit cell apoptosis and promote cell proliferation. But the expression of $\mathrm{Bcl}-2$ mRNA decreased and Bax mRNA expression increased in organic extracts group which is equivalent to the original $2000 \mathrm{~mL}$, and showed the toxic effect.

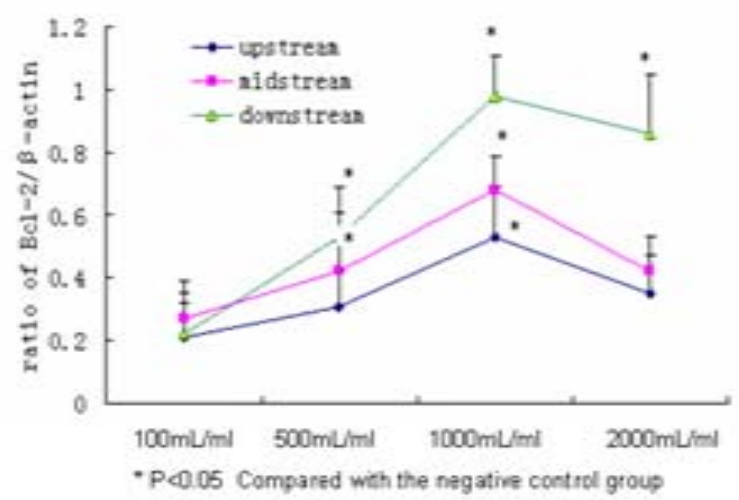

Figure 2 Bcl-2 mRNA expression of MCF-7 of organic extracts of Songhua River

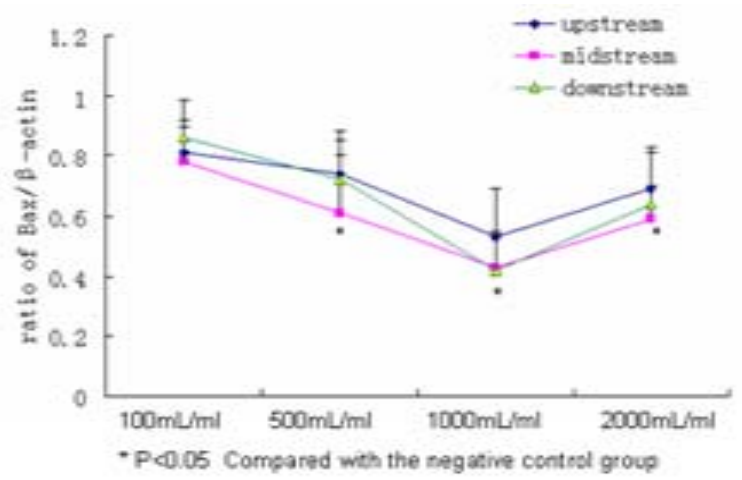

Figure3 Bax mRNA expression of MCF-7 of organic extracts of Songhua River

\section{DISCUSSION}

Songhua River is one of China's seven major rivers, is the main water source of Heilongjiang province and Jilin province. Therefore, understanding EEs pollution status of Songhua River water has important significance to lay down the water EEs pollution prevention countermeasures of Songhua River, and improve the health level of residents along the river.

Breast cancer is a common gynecological diseases, the incidence rate was more than $1 \%$ in some industrialized countries. Some people think that the etiology was relevant to environmental estrogen exposure. Environmental estrogen refers to a kind of exogenous chemicals, which can mimic or interfere natural estrogen in the body physiological function of secretion, synthetic, transport, binding, excretion .Effects of environmental estrogens on human and animal health has attracted people's attention, became one of the most important research direction of endocrine disruptors.

MCF-7 cells in this experiment derived from human breast cancer cells, is a kind of expression of estrogen receptor positive and estrogen sensitive to cells, is widely applied in the evaluation of environmental estrogen. Soto put forward evaluation the environmental estrogen using MCF-7 cell proliferation assay, called estrogen screening (E-screen)experiment. The principle is that serum contains a specific inhibition of proliferation of estrogen sensitive cell substance, called estrogen, but estrogen can neutralize substances such specifically and remove its inhibitory effect to induce cell proliferation. no estrogenic activity of steroid hormones and growth factors In serum are not neutralize the substance.

At present, the detection method of EEs in water contained with chemical analysis and biological analysis. A variety of environmental estrogenic substances were detected in positive samples by chemical analysis, theirs active effect is not one; while the experiment of human breast cancer MCF-7 cell proliferation, as a biological evaluation method ${ }^{[4]}$, can determine comprehensive activity effect of multiple environmental estrogens In this study human breast cancer MCF-7 cell proliferation experiment was used to detect estrogenic activity Jilin City reach of the second Songhua River. But the experiment require a higher conditions, medium and serum have special requirements. Therefore, in this study, experiments have to be made under carefully controlled conditions including a reasonable choice of culture medium, and the calf serum treated with activated carbon - glucan in order to eliminate the influence of estrogen in the blood, so as to ensure the reliability and accuracy of the results.

The results of this study showed that MCF- 7 cell proliferation rate increased at first and later decreased with the organic extracts concentration. Cell proliferation was the fastest in organic extracts group equivalent to the raw water $1000 \mathrm{~mL}$. In the literature, $\mathrm{Zhu} \mathrm{Yi}^{\left[{ }^{[5]}\right.}$ reported estrogen effect reaches a maximum value when organic extracts matter is equivalent to the original water $1250 \mathrm{~mL}$ in the Jialing Rive; Hu Gonghua ${ }^{[6]}$ found that when organic extracts matter is equivalent to the amount of water $2000 \mathrm{~mL}$ in Ganjiang River, estrogen effect reaches a maximum value. Compared with the other rivers, estrogen effect in Jilin City reach of the second Songhua River is not the supreme level, but the hazards can not be ignored.

In addition, we also investigated the mechanism of cell proliferation induced by organic extracts from $\mathrm{Bcl}-2$ and Bax gene .Bcl-2 and Bax is a downstream gene of wild type p53, and is apoptosis regulated genes studied in depth. Bcl-2 is the apoptosis inhibitor gene, it can inhibit cell apoptosis, prolong cell life ${ }^{[7]}$. While Bax is a pro apoptotic gene ${ }^{[8]}$, it can inhibit cell proliferation. Therefore, the simultaneous detection of Bcl-2 and Bax could reflect their regulating effect on cell apoptosis ${ }^{[9]}$. 
Wang ${ }^{[10]}$ has found the effects of estrogen (E2) found that estradiol E2 can stimulate Bcl-2 protein expression rate of MCF-7 cells cultured in vitro elevated. In this study effect on Bcl-2 and Bax mRNA expression of MCF-7 of organic extracts of Songhua River was detected by RT-PCR. We found that there is a certain dose - response relationship between Bcl-2 or bax mRNA expression with extract concentration. Bcl-2 mRNA expression of MCF-7 cell increased and Bax mRNA expression decreased with the concentration of organic matter. The results showed that the organic extract could promote cell proliferation through the regulation of $\mathrm{Bcl}-2$ and Bax expression.

\section{ACKNOWLEDGMENT}

This work was financially supported by the Science and Technological Project of Jilin Province in China (No.201205038), the Nature and Science fund from Jilin Province Ministry of Education(No.2011129).

\section{REFERENCES}

[1] Kedi Yang, environmental health/environmental hygiene,7th ed, Beijing: People's Medical Publishing House,2013,pp.213-218

[2] Safe S,"Endocrine disruptors and human health: is there a problem,"Toxicology, vol. 205,Feb.2004,pp. 3-10
[3] Magliulo L, Schreibman M P \& Cepriano J,"Endocrine disruption caused by two common pollutants at/acceptable concentrations,"Neurotoxicol Teratol,vol.24, Jan. 2002, pp.71-79

[4] Soto A M, Sonnenschein C and Chung K L, "The E-screen assay as a tool to identify estrogens: an update on estrogenic environmental pollutants. Environ Health Perspect,"vol.103,Aug.1995, pp.113122

[5] Zhu Yi, Tian Huaijun and Shu wei Qun,"Evaluation of the estrogenic activity of organic extracts from source water of Yangtze River and Jialing River in Chongqing section, "environmental pollution and control,vol. 25,Feb.2003,pp.65-67

[6] Hu Gonghua, Li Feng and Li Sisi, "Survey on the estrogen activity in organic extracts ofwater body from the Gan zhou reach of Gan jiang River," Chinese Journal of industrial medicine, vol. 20,Mar. 2009,pp.184-187

[7] Ola MS,Nawaz M and Ahsan H, "Role of Bcl-2 family proteins and caspases in the regulation of apoptosis," Mol Cell Biochem,vol.351,Jan.2011,pp.41-58

[8] Westphal D, Dewson G and Czabotar PE, "Molecular biology of Bax and Bak activation and action, "Biochim Biophys Acta, vol.1813,Apr.2011,pp.521-531

[9] Wong W W and Puthalakath $\mathrm{H}$,"Bcl-2 family proteins: the sentinels of the mitochondrial apoptosis pathway,"Iubmb Life vol.60,Jun.2008,pp.390-397

[10] Wang TTY and Phang JM,"Effects of estrogen on apoptotic pathways in human breast cancer cell line MCF-7,"Cancer Res,vol.55,Dec.1995,pp.2487-2489 